Universitätsspital Zürich

Klinik für Ohren-, Nasen-, Hals- und Gesichtschirurgie

Direktor: Prof. Dr. med. R. Probst

Arbeit unter Leitung von PD Dr. med. G. F. Huber

\title{
High sex determining region $Y$-box 2 expression is a negative predictor of occult lymph node metastasis in early squamous cell carcinomas of the oral cavity
}

\author{
INAUGURAL-DISSERTATION \\ zur Erlangung der Doktorwürde \\ der Medizinischen Fakultät \\ der Universität Zürich
}

vorgelegt von

Lena Züllig

von Bülach $\mathrm{ZH}$

Genehmigt auf Antrag von Prof. Dr. med. R. Probst

Zürich 2013 


\section{Publikationshinweis}

Publiziert am: 12. Februar 2013

Journal: Im European Journal of Cancer, Bd. 49, S. 1915-1922 


\title{
High sex determining region Y-box 2 expression is a negative predictor of occult lymph node metastasis in early squamous cell carcinomas of the oral cavity
}

\author{
L. Züllig a,f, M. Roessle ${ }^{\text {b,f }}$, C. Weber ${ }^{a}$, N. Graf ${ }^{\text {c }}$, S.K. Haerle ${ }^{a}$, W. Jochum ${ }^{\text {d }}$, \\ S.J. Stoeckli ${ }^{\mathrm{e}}$, H. Moch ${ }^{\mathrm{b}}$, G.F. Huber ${ }^{\mathrm{a}, *}$ \\ ${ }^{a}$ Otorhinolaryngology, Head and Neck Surgery, University Hospital Zurich, Frauenklinikstrasse 24, 8091 Zürich, Switzerland \\ ${ }^{\mathrm{b}}$ Institute of Surgical Pathology, University Hospital Zurich, Rämistrasse 100, 8006 Zürich, Switzerland \\ ${ }^{\mathrm{c}}$ Clinical Trials Center, Center for Clinical Research, University Hospital Zurich, Rämistrasse 100, 8091 Zürich, Switzerland \\ ${ }^{d}$ Department of Pathology, Kantonsspital St. Gallen, Rorschacher Strasse 95, 9007 St. Gallen, Switzerland \\ ${ }^{\mathrm{e}}$ Otorhinolaryngology, Head and Neck Surgery, Kantonsspital St. Gallen, Rorschacher Strasse 95, 9007 St. Gallen, Switzerland
}

\section{KEYWORDS}

Head and neck squamous cell carcinoma (HNSCC) Oral cavity

SOX2 (sex determining region Y-box 2)

Immunohistochemistry Sentinel node biopsy

\begin{abstract}
Background: The transcription factor sex determining region Y (SRY)-box 2 (SOX2) (3q26.3-q27) has been recently identified as a recurrently activated major oncogene in squamous cell carcinoma of various sites. Its prognostic value in head and neck squamous cell carcinoma (HNSCC) is currently unclear.

Aim: To correlate SOX2 protein expression with the occurrence of occult lymph node metastasis and relapse free survival in early oral SCC.

Methods: SOX2 expression in 120 T1/T2 oral SCC patients was evaluated using a tissue microarray technique. Intensity of SOX2 expression was quantified by assessing the Intensity/Reactivity Scores (IRSs). These scores were correlated with the lymph node status of biopsied sentinel lymph nodes and recurrence. Log rank univariate and Cox regression multivariate analysis was used to determine statistical significance.

Results: Twenty-six of 120 primary tumours $(21.7 \%)$ showed high SOX2 expression. High expression levels of SOX2 significantly correlated with negative lymph node status in univariate $(p=0.001)$ and multivariate analysis $(p=0.003)$. Sensitivity was found to be $95.6 \%$ with a negative predictive value of $92.3 \%$. Specificity was $32 \%$ with a positive predictive value of $45.7 \%$.
\end{abstract}

\footnotetext{
* Corresponding author: Tel.: +41 255 5860/5851.

E-mail address: gerry.huber@usz.ch (G.F. Huber).

${ }^{f}$ These authors contributed equally to this work.
} 
Conclusion: SOX2 up-regulation is frequent in early SCC of the oral cavity and associated with decreased risk of lymphatic metastasis. SOX2 immunohistochemistry may be used as a predictor for lymph node metastasis in squamous cell carcinoma of the oral cavity.

(C) 2013 Elsevier Ltd. All rights reserved.

\section{Introduction}

Head and neck squamous cell carcinoma (HNSCC) is the fifth-most common solid tumour diagnosed in the world. The oral cavity is the most commonly affected subsite $(274,000$ cases) and ranks as the 12 th most common cancer. ${ }^{1}$ Advances in surgical and radio-oncological management over the years have unfortunately not significantly improved oncological outcomes for advanced cases, though ever more selective approaches to the neck and though innovative flap/reconstruction techniques have lowered morbidity and improved function. Involvement of regional lymph nodes at diagnosis roughly halves 5-year survival. $^{2}$

Several oncogenes have been identified in oral SCC. Sex determining region Y (SRY)-box 2 (SOX2), a transcription factor-coding gene located on 3q26.3$27,{ }^{3}$ has recently been shown to be frequently amplified in SCCs of oesophagus and lung SCC. ${ }^{4,5}$ In oral squamous cell carcinoma, SOX2 has also been reported to be amplified and overexpressed. ${ }^{6}$ It encodes a transcription factor involved in the determination of cell fate and regulation of embryonic development. After creating a protein complex with other proteins it acts as a transcriptional activator that is essential to maintain self-renewal of undifferentiated embryonic stem cells. ${ }^{7-10}$ As forced Oct4 expression induces pluripotency in SOX2-null cells, a group of researchers have concluded that the primary role of SOX2 in induced pluripotent stem cells is controlling Oct4 expression, and that they perpetuate their own expression when expressed concurrently. ${ }^{11}$ Several recent publications implicate a substantial role of SOX2 as prognostic factor for squamous cell carcinoma of various sites. SOX2 amplification was identified by FISH in 20 $23 \%$ of lung cancer; $11-15 \%$ of oesophagus cancer, $5-28 \%$ of cervix SCC and $28 \%$ of skin cancer. ${ }^{4,5,12}$ In lung cancer, SOX2 overexpression is associated with favourable prognosis, whereas the relevance of SOX2 expression for prognosis of HNSCC is controversial. $^{13-15}$

Sentinel node biopsy (SNB) of the N0 neck in early oral SCC has been shown in several studies to reliably detect occult neck metastasis with negative predictive values $>95 \%$. To clarify a potential prognostic relevance for occult metastasis of SOX2 protein expression, we consequently analysed a very well defined patient cohort with early oral SCC (T1/T2-stage) undergoing sentinel lymph node biopsy. ${ }^{16,17}$

\section{Patients and methods}

Permission for performing the study was obtained from the local ethics committee.

Detailed information of patient recruitment and surgical procedure (including surgical resection of the primary tumour and SNB) can be found in former articles by our group. ${ }^{18,19}$ In brief, 133 patients of the ear nose and throat departments of the University Hospital of Zurich and the Kantonsspital St. Gallen, Switzerland, with early stage (T1/T2) SCC of the oral cavity and the tonsillar pillar without preoperative clinical and imaging evidence of regional lymph node metastasis were selected for this study. SCCs of the tonsillar pillar were included, because they behave similarly to oral cavity carcinoma rather than Human Papilloma Virus (HPV)-positive tonsillar carcinoma. ${ }^{20}$ Due to the established fact, that a subgroup of oral and oropharyngeal SCC is caused by HPV infection, ${ }^{21}$ p16 immunohistochemistry was used as a surrogate marker of HPV status. $^{22}$

For SNB, the radioactive tracer was injected preoperatively into the region of the primary tumour. Sentinel lymph nodes (SLN) were intraoperatively located by use of a gammaprobe, excised and subjected to immediate frozen section analysis. If occult metastases were identified, a completion modified radical neck dissection was performed in the same sitting. ${ }^{17}$ Patients whose definitive histology showed a positive SNB underwent interval neck dissection.

Formalin-fixed, paraffin-embedded primary tumour tissues of the 133 patients were histopathologically reevaluated. 13 patients were excluded from the analysis because of loss of follow-up or inability to appropriately evaluate the paraffin block. The mean clinical follow-up of the remaining 120 patients (111 from Zurich, nine from St. Gallen) was 81 months (range 11-122). Fig. 1 summarises the patients enrolled in this study (consort diagram). Mean patient age was 59 years (range 2888 ). The tumour locations were in the oral cavity proper $(110 / 120(91.7 \%)$; mostly tongue) and the palatine arch $(10 / 120(8.3 \%))$. Male:female ratio was 82:38 (2.16:1). 64 patients were staged pT1 and $56 \mathrm{pT} 2$. Both sides of the oral cavity were equally involved. $11 \%$ of tumours were found in the midline. Table 2 gives a synopsis over the clinical parameters.

For the construction of a tissue microarray (TMA) a morphologically representative region of the "donor" paraffin blocks with primary tumour tissue was selected. From this representative section two core biopsies 
(diameter, $0.6 \mathrm{~mm}$; height, 3-4 mm) from the invading front were taken and precisely arrayed into a new "recipient" paraffin block using a custom-built instrument. ${ }^{23}$ After the block production was finished, 4.0$\mu \mathrm{m}$ sections of the resulting tumour TMA block were cut for further analysis as recently described. ${ }^{24,25}$

SOX2 immunohistochemistry was performed using the rabbit monoclonal SOX2 antibody (1:100, Clone EPR3131, Epitomics, Inc.) and a monoclonal mouse anti-p16 antibody (clone JC8, 1:200, Santa Cruz Biotechnology, Santa Cruz, CA, USA) on a Ventana Benchmark automated staining system (Ventana Medical Systems Inc., Tucson, AZ, USA) as recently described. $^{26}$ For SOX2, extranuclear staining was regarded to be negative or unspecific. Immunohistochemistry was evaluated in two cores per tumour. The average percentage was taken for statistical analysis. SOX2 staining intensity was measured by the Intensity/Reactivity Score (IRS), which is frequently applied for a detailed expression analysis of transcription factors. Staining intensity (SI) was assessed to be negative $(=0)$, weak $(=1)$, moderate $(=2)$ or strong staining $(=3)$. Reactivity $(\mathrm{R})$ was determined by the percentage of positive tumour cells (PP) and scored as follows: negative $(=0), \quad 1-10 \%$ positive cells $(=1), \quad 11-30 \%$ $(=2), 31-50 \%(=3), 51-80 \%(=4)$ and $>80 \%$ positive cells $(=5)$. IRS was calculated by multiplying PP with SI (minimum 0/maximum 15). High expression was defined as $\geqslant 8$ according to the median IRS of positive stained cells.

According to recent literature, ${ }^{22}$ a strong and diffuse, nuclear and cytoplasmic staining reaction of p16 in a majority of tumour cells was considered as indicative for an HPV-associated carcinoma.

\subsection{Statistics}

The relationship between presence of lymph node metastasis and SOX2 expression was evaluated using Fisher's exact test. The predictive power of SOX2 expression for lymph node metastasis was evaluated with a logistic regression controlling for grade of differentiation and tumour stage. Tumour differentiation was not included as a factor in the logistic regression model for the reason of "quasi" complete separation in the data. In order to evaluate the potential of SOX2 as a predictive marker for occult metastasis and eventually for relapse time, a logistic regression and a KaplanMeier survival analysis was performed. The possible value of SOX2 expression as a predictive marker for occult metastasis was additionally specified with calculation of sensitivity, specificity, positive and negative predictive values. How sensitivity and specificity were calculated is illustrated in Table 1. Positive and negative predictive values were calculated accordingly.

A Kaplan-Meier curve with calculation of log rank statistics was performed to compare survival and relapse rates, respectively, between patients with high and low expression. PASW Statistics 18.0.0 for windows (SPSS) was used for statistical analyses.

\section{Results}

SOX2 protein expression was virtually exclusively identified in the nucleus of the tumour cells (Fig. 2). Twenty-six of $120(21.7 \%)$ of the primary tumours showed a high SOX2 expression and 23/120 (19.2\%) were negative. For statistical analysis, tumours were categorised according to the median value of stained

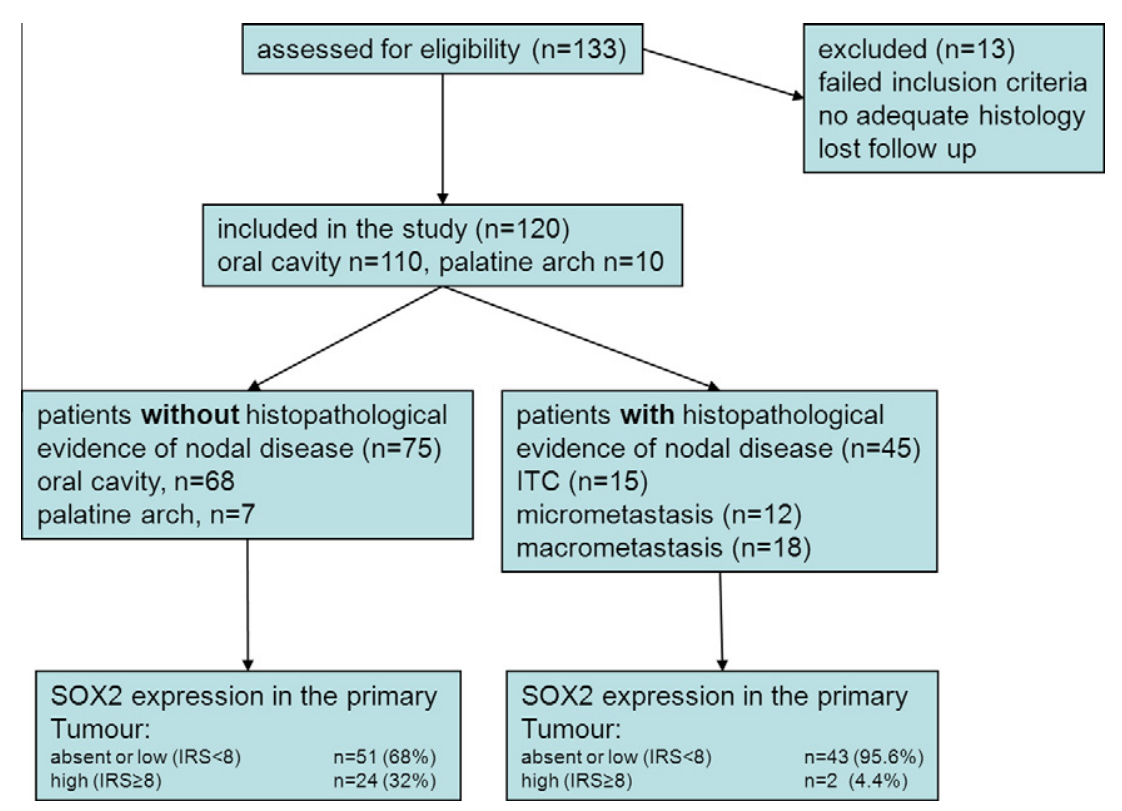

Fig. 1. Consort diagram of the patients included in the study. ITC $=$ Isolated tumour cells/IRS $=$ Intensity/Reactivity Score. 
Table 1

Calculation of sensitivity and specificity depending on SOX2 expression ("2 $2 \times 2$ table").

\begin{tabular}{|c|c|c|c|c|}
\hline & & \multicolumn{3}{|c|}{ "Gold standard" = result of sentinel node biopsy } \\
\hline & & $\begin{array}{l}\text { Occult metastatic } \\
\text { disease: Yes }\end{array}$ & $\begin{array}{l}\text { Occult metastatic } \\
\text { disease: No }\end{array}$ & \\
\hline \multirow[t]{4}{*}{$\begin{array}{l}\text { New predictive marker for occult metastatic } \\
\text { disease (SOX2) }\end{array}$} & & True positive & False positive & $\begin{array}{l}\text { All test } \\
\text { positives }\end{array}$ \\
\hline & $\begin{array}{l}\text { Low SOX2 } \\
\text { expression }\end{array}$ & a & $\mathrm{b}$ & $a+b$ \\
\hline & $\begin{array}{l}\text { High SOX2 } \\
\text { expression }\end{array}$ & $\mathrm{c}$ & $\mathrm{d}$ & $\begin{array}{l}\mathrm{c}+\mathrm{d} \\
\text { All test } \\
\text { negatives }\end{array}$ \\
\hline & & $\begin{array}{l}\mathrm{a}+\mathrm{c} \\
\text { All with occult disease }\end{array}$ & $\begin{array}{l}\mathrm{b}+\mathrm{d} \\
\text { All without occult } \\
\text { disease }\end{array}$ & \\
\hline
\end{tabular}

Hypothesis: high SOX2 expression predicts absence of occult metastatic disease.

Sensitivity: $\mathrm{c} /(\mathrm{a}+\mathrm{c})$.

Specificity: $b /(b+d)$

Table 2

Association of SOX2 with tumour stage, differentiation and lymph node status.

\begin{tabular}{|c|c|c|c|}
\hline & SOX2 low (Intensity/Reactivity Score (IRS) $0-7) n=94(78.3 \%)$ & SOX2 high (IRS 8-15) $\mathrm{n}=26(21.7 \%)$ & $p$-Value \\
\hline \multicolumn{4}{|l|}{ Tumour stage } \\
\hline $\mathrm{pT} 1$ & $48(51.1 \%)$ & $16(61.5 \%)$ & \multirow[t]{2}{*}{$0.381^{\mathrm{a}}$} \\
\hline pT2 & $46(48.9 \%)$ & $10(38.5 \%)$ & \\
\hline \multicolumn{4}{|l|}{ Differentiation grade $^{*}$} \\
\hline Grade I (low) & $13(14.8 \%)$ & $5(20.8 \%)$ & \multirow[t]{3}{*}{$0.360^{\mathrm{b}}$} \\
\hline Grade II (moderate) & $63(71.6 \%)$ & $17(70.8 \%)$ & \\
\hline Grade III (high) & $12(13.6 \%)$ & $2(8.3 \%)$ & \\
\hline \multicolumn{4}{|l|}{ Sentinel node } \\
\hline Negative & $51(54.3 \%)$ & $24(92.3 \%)$ & \multirow[t]{2}{*}{$0.001^{\mathrm{a}}$} \\
\hline Positive & $4(5.7 \%)$ & $2(7.7 \%)$ & \\
\hline
\end{tabular}

* Eight patients with differentiation grade not otherwise specified had to be excluded.

${ }^{\text {a }}$ Fisher's exact test.

b Exact Mann-Whitney $U$ test.

positive cells into 3 categories: negative, low expressors (IRS $=1-7)$ and high expressors (IRS $=8-15$ ). These groups were then compared to clinical course. There was no association between SOX2 protein expression and tumour differentiation grade or with tumour stage (Table 2). High SOX2 expression correlated with negative lymph node status $(p=0.001)$ (Table 2, Fig. 3), regardless of p16 state. After controlling for tumour stage, SOX2 expression remained a significant predictor for lymph node status (odds ratio $(\mathrm{OR})=0.102,95 \%$ confidence interval (CI): $0.023-0.457, \quad p=0.003$; Table 3).

SOX2 expression showed a sensitivity of $95.6 \%(95 \%$ CI: $84.9-99.5 \%)$ and a specificity of $32.0 \%(95 \%$ CI: $21.7-43.8 \%$ ) with regard to presence or absence of lymph node metastasis. The positive predictive value was $45.7 \%$ and the negative predictive value was $92.3 \%$.

SOX2 expression was also evaluated for a possible effect on relapse rates. However, the log rank test did not indicate any influence of SOX2 expression on relapse rates. Gender, tumour location, side and T-stage were not found to relate to occult metastasis.

\section{1. p16 immunohistochemistry}

Strong and diffuse, nuclear and cytoplasmic immunohistochemical p16 expression was detected in eleven of 120 tumours $(9.2 \%)$. Ten of 110 tumours of the oral cavity $(9.1 \%)$ and one of ten oropharyngeal SCC (10\%) were p16-positive, suggesting an HPV-associated carcinogenesis. p16 could therefore be excluded as a relevant confounder.

\section{Discussion}

In our study, we demonstrate that approximately $80 \%$ of early stage SCC of the oral cavity expresses SOX2. High expression of SOX2 in these tumours is associated with a significantly lower incidence of occult metastasis in neck lymph nodes. 


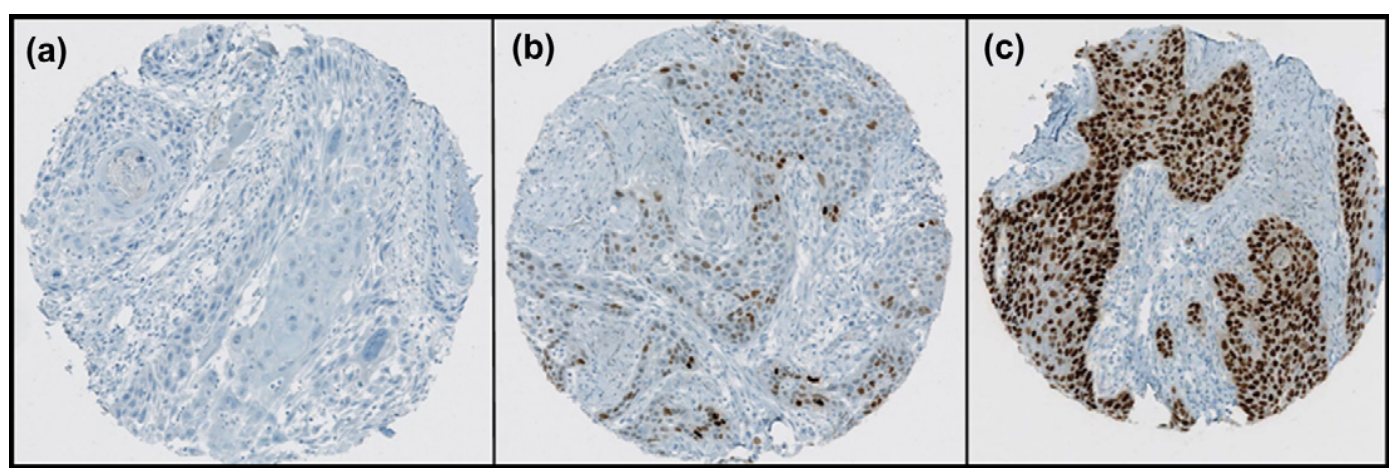

Fig. 2. SOX2 immunohistochemistry of primary tumours: (a) absent expression, (b) low nuclear expression, (c) high nuclear expression.

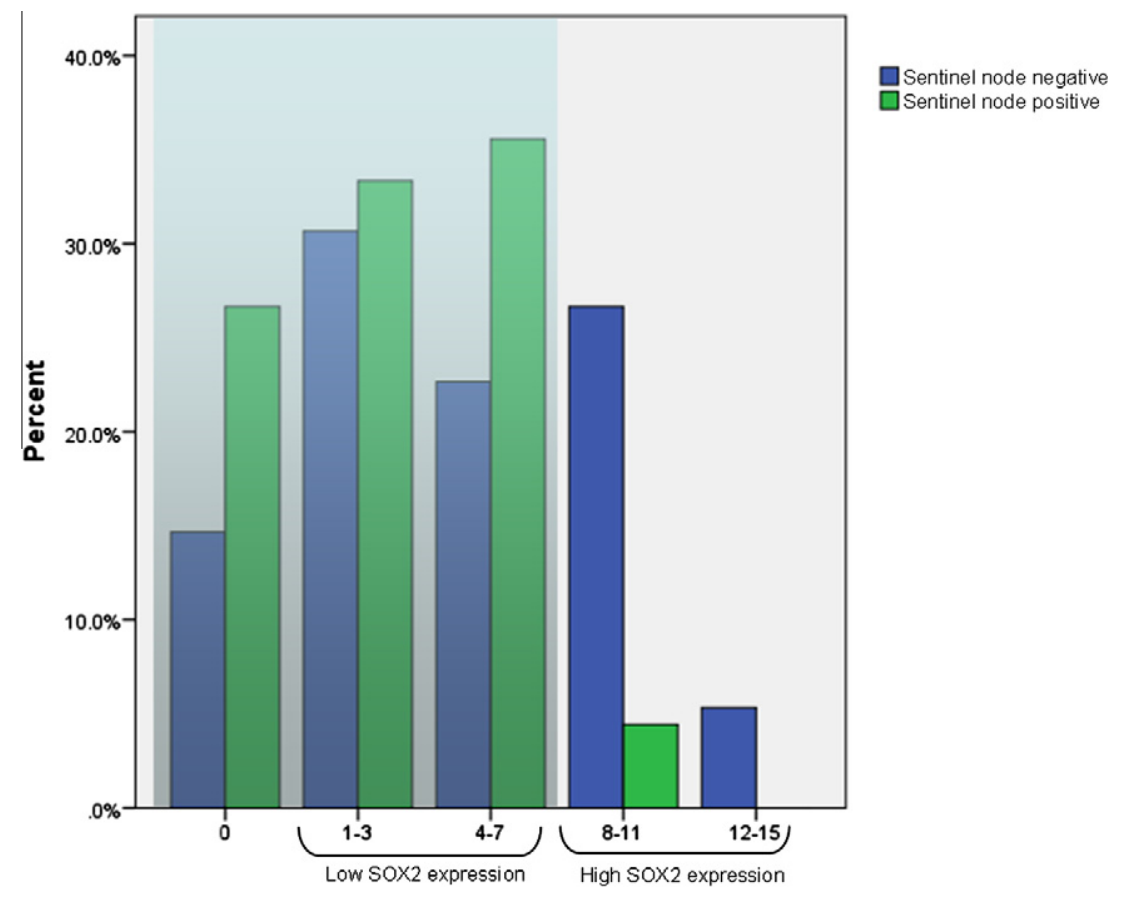

Fig. 3. Sentinel status according SOX2 expression levels: While in none- and low expressors (Intensity/Reactivity Score (IRS) 0-7) sentinel node negative patients overweigh sentinel node positive patients, in high expressors (8-15) most patients were found to be negative for occult metastatic disease.

The high SOX2 expression in early SCC of the oral cavity is consistent with the hypothesis that SOX2 is the target of chromosomal amplifications observed in the 3q26-qter region by previous comparative genomic hybridisation (CGH) studies. Copy number increases of the 3q26-qter region have been identified in different SCCs, including lung, oesophagus and cervix. ${ }^{27-30}$ The presence of frequent copy number gains/amplifications suggested the presence of a relevant proto-oncogene in this region.

SOX2 was first reported to be amplified in SCCs of oesophagus and lung, ${ }^{4,5}$ but also in SCC of the cervix uteri, the skin and the penis. ${ }^{12}$

Freier et al. ${ }^{6}$ identified SOX2 as potential target of the $3 \mathrm{q}$ gains/amplifications in HNSCC by array-CGH and demonstrated high SOX2 protein expression in about $18.1 \%(49 / 271)$ of oral SCC, using a polyclonal rabbit anti-SOX2 antibody (Chemicon, Millipore, MA). We observed a similar frequency of high SOX2 expression $(21 \%)$ with a different monoclonal antibody (Epitomics).

Our result is consistent with a very high expression level of nuclear SOX2 protein in the majority of primary SCC, but high SOX2 expression has also been found in breast cancer, ${ }^{31}$ testicular germ cell tumours, ${ }^{32}$ as well as gastric ${ }^{33}$ and pancreatic adenocarcinoma. ${ }^{34}$ The mechanisms for SOX2 protein overexpression are unclear. SOX2 protein expression has also been reported in tumours without gene amplifications. ${ }^{6,12}$ Interestingly, SOX2 amplifications are obviously specific for SCC 
Table 3

Logistic regression: Adjusted odds ratios (ORs), 95\% confidence intervals ( $95 \% \mathrm{CIs})$ and $p$-value of SOX2 expression and tumour stage as predictors for lymph node status. Because of quasi-complete separation in the data, differentiation grade was not included as a factor in the logistic regression model.

\begin{tabular}{llll}
\hline Predictor & OR & $95 \%$ CI & $p$-Value \\
\hline $\begin{array}{l}\text { SOX2 expression } \\
\text { High versus low }\end{array}$ & 0.102 & $0.023-0.457$ & 0.003 \\
$\begin{array}{l}\text { Tumour stage } \\
\text { pT2 versus pT1 }\end{array}$ & 1.665 & $0.758-3.659$ & 0.204 \\
\hline
\end{tabular}

pathogenesis, because adenocarcinomas of the lung or cervix have no SOX2 amplifications, ${ }^{12}$ but high SOX2 protein expression.

In our well characterised cohort of early SCC of the oral cavity, we were able to study the process of early lymphatic metastasis and demonstrate a significant association between high cancer cell-expressed SOX2 protein and significant lower risk of lymph node metastasis. This result is consistent with findings in lung SCC, ${ }^{35}$ reporting high SOX2 protein expression levels and SOX2 amplification to be correlated with better overall survival. The relationship between SOX 2 expression and tumour behaviour is highly controversial. It is intriguing that there are some studies reporting increased aggressive behaviour of tumour cells with SOX2 expression. $\mathrm{Du}$ et al. ${ }^{13}$ showed a significant association of high SOX2 expression in nodal negative oral tongue carcinoma with poor overall and disease-free survival using the same interpretation method of the immunohistochemical results, but a different antibody (Novus Biologicals). In their cohort of oral tongue SCC, 17.1\% had a high SOX2 score. There are different explanations for such controversial results:

(i) Different results may be explained by the design of retrospective studies. The problem of many studies investigating predictive markers is the heterogeneity of primary tumours (location, T-stage and Nstage), which are then analysed together. Since patients qualifying for a sentinel node biopsy yield a highly selected cohort (regarding tumour location and $\mathrm{N}$-stage) with no clinical evidence of lymph node disease, we had the possibility to detect cancers with occult metastatic disease at the earliest time point.

(ii) Discrepancies could also be explained by the selection of tumours with different $\mathrm{pT}$ stages. Our study included only T1/T2 carcinoma, whereas Du et al. also included T3 SCC ( $30 \%$ of the cases). The size of their primary tumours correlated significantly with SOX2 expression. The multivariate analysis by $\mathrm{Du}$ et al. showed that SOX2 as well as T-stage were independent prognostic factors for unfavourable overall, cancer-specific and disease-free sur- vival. Therefore, it remains unclear, which factor (T-stage, lymph node metastasis or SOX2 expression) was most important for patients' outcome.

(iii) A biological reason for a different prognostic role of SOX2 in different tumour types could be the involvement of additional oncogenes. In a metaphase comparative genomic hybridisation (CGH) analysis, overrepresentation of the chromosomal region 3q21-q29 was associated with decreased overall and disease-free survival suggesting that $3 q$ gains are involved in HNSCC progression. ${ }^{36}$ Several candidate proto-oncogenes are located within this chromosomal arm, including PIK3CA and $C C N L 1$. Amplification and protein expression of $P I K 3 C A^{37}$ and $C C N L 1$ were reported in primary $\mathrm{HNSCC}^{38}$ and implicated in the progression of HNSCC. CCNL1 amplification was associated with the presence of lymph node metastasis, but the prevalence of this amplification was relatively low.

(iv) In a recent review by Hussenet et al., ${ }^{39}$ a pleiotropic oncogenic role of SOX2 in lung SCC was discussed: SOX2 overexpression seems to increase the precursor basal cell and may be a triggering event in the lung SCC pathogenesis. Furthermore it seems, that SOX2 overexpression in cancer stem cells (CSC) of lung SCC did not mediate selfrenewal like in CSC of glioblastoma, but leads to more differentiated cancer cells. Finally the binding of SOX2 to different co-factors and the activation of different downstream targets can result in a very different aggressiveness of the tumour. It is tempting to speculate that SOX2 has a similar influence on tumour progression of HNSCC.

According to our data, SOX2 is a potential predictive marker for a negative neck SLN in early SCC of the oral cavity. Sentinel node biopsy has been successfully validated for early HNSCC. However, use of SNB alone or SNB assisted elective neck dissection is still controversially discussed for staging and treatment of the $\mathrm{cN} 0$ neck in patients with early HNSCC. In addition, SNB is not abundantly available and to date mostly reserved for tertiary referral centres. The hitherto published predictive factors for metastatic disease in SNB include histomorphological parameters of the primary tumour including mode of invasion (morphological appearance of the infiltrating tumour front), grade of differentiation, lymphatic invasion and intratumoural lymphatic density. ${ }^{40}$ In our recent study, ${ }^{41}$ all these parameters failed to predict metastasis in SNB of oral SCC. Therefore, additional biomarkers may be of help for better patient stratification to select for SNB or elective neck dissection. In a previous study, we demonstrated that expression of E-Cadherin $(E C A D)^{19}$ significantly correlated with occult metastatic disease. In the future, a combination of molecular 
markers like SOX2, ECAD,${ }^{19}$ podoplanin,${ }^{18,25}$ p16, bmi$1,{ }^{42}$ Lysyl Oxidase $(\mathrm{LOX})^{43}$ and histomorphologic parameters may be used to stratify patients for the appropriate surgical lymph node procedure (SNB alone versus SNB assisted elective neck dissection) according to their risk for occult nodal disease. This would allow individual risk stratification with implications then for treatment strategy.

In summary, we provide evidence that up-regulation of cancer cell-expressed SOX2 correlates with lower incidence of lymph node metastasis in early SCC of the oral cavity. While SOX2 might not be applicable as a predictive marker as a single test, SOX2 immunohistochemistry in combination with other molecular markers might contribute to a more patient tailored treatment.

\section{Conflict of interest statement}

None declared.

\section{Acknowledgements}

We like to thank Mrs. Martina Storz for the TMA production and technical support, Dr. Thomas Pézier for the manuscript revision and our Grant sponsor: Olga Mayenfisch Stiftung, Toblerstrasse 83, 8044 Zürich.

\section{References}

1. Ferlay J, Bray F, Pisani P, Parkin DM. GLOBOCAN 2002. Cancer incidence, mortality and prevalence worldwide (IARC CancerBase No.5. version 2.0). Lyon: IARC Press; 2004.

2. Grandi C, Alloisio M, Moglia D, et al. Prognostic significance of lymphatic spread in head and neck carcinomas: therapeutic implications. Head Neck Surg 1985;8(2):67-73.

3. Stevanovic M, Zuffardi O, Collignon J, Lovell-Badge R, Goodfellow P. The cDNA sequence and chromosomal location of the human SOX2 gene. Mamm Genome 1994;5(10):640-2.

4. Bass AJ, Watanabe H, Mermel CH, et al. SOX2 is an amplified lineage-survival oncogene in lung and esophageal squamous cell carcinomas. Nat Genet 2009;41(11):1238-42.

5. Hussenet $\mathrm{T}$, Dali $\mathrm{S}$, Exinger $\mathrm{J}$, et al. SOX2 is an oncogene activated by recurrent $3 \mathrm{q} 26.3$ amplifications in human lung squamous cell carcinomas. PLoS One 2010;5(1):e8960.

6. Freier K, Knoepfle K, Flechtenmacher C, et al. Recurrent copy number gain of transcription factor SOX2 and corresponding high protein expression in oral squamous cell carcinoma. Genes Chromosomes Cancer 2010;49(1):9-16.

7. Takahashi K, Tanabe K, Ohnuki M, et al. Induction of pluripotent stem cells from adult human fibroblasts by defined factors. Cell 2007;131:861-72.

8. Kashyap V, Rezende N, Scotland K, et al. Regulation of stem cell pluripotency and differentiation involves a mutual regulatory circuit of the NANOG, OCT4, and SOX2 pluripotency transcription factors with polycomb repressive complexes and stem cell microRNAs. Stem Cells Dev 2009;18(7):1093-108.

9. Rizzino A. Sox 2 and Oct-3/4: a versatile pair of master regulators that orchestrate the self-renewal and pluripotency of embryonic stem cells. Wiley Interdiscip Rev Syst Biol Med 2009;1(2):228-36.

10. Zhao R, Daley GQ. From fibroblasts to iPS cells: induced pluripotency by defined factors. $J$ Cell Biochem 2008;105(4):949-55.
11. Masui S, Nakatake Y, Toyoka Y, et al. Pluripotency governed by Sox2 via regulation of Oct $3 / 4$ expression in mouse embryonic stem cells. Nat Cell Biol 2007;9(6):625-35.

12. Maier S, Wilbertz T, Braun M, et al. SOX2 amplification is a common event in squamous cell carcinomas of different organ sites. Hum Pathol 2011;42(8):1078-88.

13. Du L, Yang Y, Xiao X, et al. Sox 2 nuclear expression is closely associated with poor prognosis in patients with histologically node-negative oral tongue squamous cell carcinoma. Oral Oncol 2011;47(8):709-13.

14. Ge N, Lin HX, Xiao XS, et al. Prognostic significance of Oct4 and Sox 2 expression in hypopharyngeal squamous cell carcinoma. $J$ Transl Med 2010;12(8):94.

15. Wilbertz T, Wagner P, Petersen K, et al. SOX2 gene amplification and protein overexpression are associated with better outcome in squamous cell lung cancer. Mod Pathol 2011;24(7):944-53.

16. Stoeckli SJ, Pfaltz M, Ross GL, et al. The second international conference on sentinel node biopsy in mucosal head and neck cancer. Ann Surg Oncol 2005;12(11):919-24.

17. Stoeckli SJ. Sentinel node biopsy for oral and oropharyngeal squamous cell carcinoma of the Head and Neck. Laryngoscope 2007;117:1539-51.

18. Huber GF, Fritzsche FR, Züllig L, et al. Podoplanin expression correlates with sentinel lymph node metastasis in early squamous cell carcinomas of the oral cavity and oropharynx. Int $J$ Cancer 2010;129(6):1404-9.

19. Huber GF, Züllig L, Soltermann A, et al. Down regulation of E-Cadherin (ECAD) - a predictor for occult metastatic disease in sentinel node biopsy of early squamous cell carcinomas of the oral cavity and oropharynx. BMC Cancer 2011;11(217):1-8.

20. Rhys Evans PH. Tumours of the oropharynx and lymphomas of the head and neck. In: Kerr AG, editor. Scott-Brown's otolaryngology, vol. 6, 6th ed. London: Butterworth; 1997.

21. Gillison ML, D'Souza G, Westra W, et al. Distinct risk factor profiles for human papillomavirus type 16-positive and human papillomavirus type 16-negative head and neck cancers. $J$ Natl Cancer Inst 2008;100(6):407-20.

22. Jordan RC, Lingen MW, Perez-Ordonez B, et al. Validation of methods for oropharyngeal cancer HPV status determination in US cooperative group trials. Am J Surg Pathol 2012;36(7):945-54.

23. Kononen J, Bubendorf L, Kallioniemi A, et al. Tissue microarrays for high-throughput molecular profiling of tumour specimens. Nat Med 1998;4:844-7.

24. Hinterberger M, Reineke T, Storz M, Weder W, Vogt P, Moch H. D2-40 and calretinin - a tissue microarray analysis of 341 malignant mesotheliomas with emphasis on sarcomatoid differentiation. Mod Pathol 2007;20(2):248-55.

25. Cueni LN, Hegyi I, Shin JW, et al. Tumour lymphangiogenesis and metastasis to lymph nodes induced by cancer cell expression of podoplanin. Am J Pathol 2010;177(2):1004-16.

26. Cao XJ, Hao JF, Yang XH, et al. Prognostic value of expression of EGFR and $\mathrm{nm} 23$ for locoregionally advanced nasopharyngeal carcinoma. Med Oncol 2012;29(1):263-71.

27. Heselmeyer K, Macvill M, Schröck E, et al. Advanced-stage cervical carcinomas are defined by a recurrent pattern of chromosomal aberrations revealing high genetic instability and a consistent gain of chromosome arm 3q. Genes Chromosom Cancer 1997;19(4):233-40.

28. Liehr T, Ries J, Wolff E, et al. Gain of DNA copy number on chromosomes 3q26-qter and 5p14-pter is a frequent finding in head and neck squamous cell carcinomas. Int $\mathrm{J}$ Mol Med 1998;2(2):173-9.

29. Tada K, Oka M, Hayashi H, Tangoku A, Oga A, Sasaki K. Cytogenetic analysis of esophageal squamous cell carcinoma cell lines by comparative genomic hybridization: relationship of cytogenetic aberrations to in vitro cell growth. Cancer Genet Cytogenet 2000;117(2):108-12. 
30. Chujo M, Noguchi $T$, Miura $T$, Arinaga $M$, Uchida $Y$, Tagawa Y. Comparative genomic hybridization analysis detected frequent overrepresentation of chromosome $3 \mathrm{q}$ in squamous cell carcinoma of the lung. Lung Cancer 2002;38(1):23-9.

31. Chen Y, Shi L, Zhang L, et al. The molecular mechanism governing the oncogenic potential of SOX2 in breast cancer. $J$ Biol Chem 2008;283(26):17969-78.

32. Biermann K, Heukamp LC, Steger K, et al. Genome-wide expression profiling reveals new insights into pathogenesis and progression of testicular germ cell tumours. Cancer Genomics Proteomics 2007;4(5):359-67.

33. Tsukamoto T, Mizoshita T, Mihara M, et al. Sox2 expression in human stomach adenocarcinomas with gastric and gastric-andintestinal-mixed phenotypes. Histopathology 2005;46(6):649-58.

34. Sanada Y, Yoshida K, Ohara M, Oeda M, Konishi K, Tsutani Y. Histopathologic evaluation of stepwise progression of pancreatic carcinoma with immunohistochemical analysis of gastric epithelial transcription factor SOX2: comparison of expression patterns between invasive components and cancerous or nonneoplastic intraductal components. Pancreas 2006;32(2):164-70.

35. $\mathrm{Lu} \mathrm{Y,} \mathrm{Futtner} \mathrm{C,} \mathrm{Rock} \mathrm{JR,} \mathrm{et} \mathrm{al.} \mathrm{Evidence} \mathrm{that} \mathrm{SOX2}$ overexpression is oncogenic in the lung. PLoS One 2010;5(6):e11022

36. Liu CJ, Lin SC, Chen YJ, Chang KM, Chang KW. Arraycomparative genomic hybridization to detect genomewide changes in microdissected primary and metastatic oral squamous cell carcinomas. Mol Carcinog 2006;45(10):721-31.

37. Bockmühl U, Schlüns K, Küchler I, Petersen S, Petersen I. Genetic imbalances with impact on survival in head and neck cancer patients. Am J Pathol 2000;157(2):369-75.

38. Redon R, Hussenet T, Bour G, et al. Amplicon mapping and transcriptional analysis pinpoint cyclin $\mathrm{L}$ as a candidate oncogene in head and neck cancer. Cancer Res 2002;62(21):6211-7.

39. Hussenet T, du Manoir S. SOX2 in squamous cell carcinoma: amplifying a pleiotropic oncogene along carcinogenesis. Cell Cycle 2010;9(8):1480-6.

40. Chung MK, Min J-Y, So YK, et al. Correlation between lymphatic vessel density and regional metastasis in squamous cell carcinoma of the tongue. Head Neck 2010;32(4):445-51.

41. Goerkem M, Braun J, Stoeckli S. Evaluation of clinical and histomorphological parameters as potential predictors of occult metastases in sentinel lymph nodes of early squamous cell carcinoma of the oral cavity. Ann Surg Oncol 2010;17(2):527-35.

42. Huber GF, Albinger A, Soltermann A, et al. Expression patterns of Bmi-1 and p16 significantly correlate with overall, disease specific and recurrence free survival in oropharyngeal squamous cell carcinoma (OSCC). Cancer 2011 [Epub ahead of print].

43. Albinger-Hegyi A, Stoeckli SJ, Schmid S, et al. Lysyl oxidase expression is an independent marker of prognosis and a predictor of lymph node metastasis in oral and oropharyngeal squamous cell carcinoma (OSCC). Int J Cancer 2010;126(11):2653-62. 


\section{Verdankungen}

Gebührender Dank für die herausragende Betreuung an meinen Doktorvater PD Dr. med. Gerhard F. Huber, der diese Dissertation mit viel Fachwissen und Engagement geleitet und mir einen spannenden, interessanten und lehrreichen Einblick in die Welt der Forschung und Kongresse ermöglicht hat.

Martina Storz und ihrem Team danke ich herzlichst für die kompetente Unterstützung bei der Arbeit im TMA-Labor.

Ebenfalls meinen Dank aussprechen möchte ich meiner Familie und meinen Freunden für das stets vorhandene Interesse an meiner Dissertation sowie für die persönliche Unterstützung im Laufe der Arbeit. 


\section{Erläuterung zur Arbeit}

Die Dissertantin begann ihre Arbeit unter der Leitung von PD Dr. med. Gerhard F. Huber im Juli 2009. Es erfolgte in einem ersten Schritt ein ausgedehntes Literaturstudium zur Bestimmung der potentiell meistversprechendsten prädiktiven Marker der lymphogenen Metastasierung von p1 und p2 Karzinomen der Mundhöhle und des Oropharynx. Es wurden zunächst die Marker E-Cadherin, p16, Cyclin D1 und EGFR, später N-Cadherin, Periostin, Vimentin, Podoplanin sowie SOX-2 studiert. Zu diesen erfolgte das Zusammenstellen der wichtigsten Informationen durch die Dissertantin zu Handen des Dissertationsbetreuers.

Die zu untersuchende Kohorte umfasste 133 Patienten aus dem ORL-Departement des Universitätsspitals Zürich und neun aus dem ORL-Departement des Kantonspitals St. Gallen. Es erfolgte das zeitaufwändige Erstellen des Tissue Micro Array (nachfolgend TMA) in

Zusammenarbeit mit der Klinischen Pathologie des Universitätsspitals Zürich. Bei einem TMA werden ausgestanzte Gewebezylinder in einen Paraffinblock eingebettet, geschnitten und angefärbt. Je nach Grösse dieser Gewebezylinder, den sogenannten Cores, können mit dieser Methode bis zu 1000 Proben von verschiedenen Patienten auf einem Objektträger gleichzeitig untersucht werden. Abhängig von der Dicke der Cores können von einem TMA bis zu 500 Schnitte gemacht und gefärbt werden.

Der Dissertantin oblag es, die 133 Patienten anhand ihrer Patientennummer im Klinikinformationssystem zu identifizieren und die im Computersystem der Klinischen Pathologie hinterlegten Pathologieberichte zu studieren. Im Falle der neun Patienten des Kantonssitals St. Gallen organisierte sie die entsprechenden Tumorblöcke. In einem zweiten Schritt erfolgte das Bestellen der nach Hämatoxylin-Eosin gefärbten-Schnitte (nachfolgend HE-Schnitt) der archivierten, in Paraffin eingebetteten 120 Tumor- sowie 10 Sentinellymphknotenresektate. Die bei einer Operation gewonnenen Gewebeteile werden jeweils einzeln in einen Paraffinblock eingebettet, dies bedeutet, dass von den in der Kohorte eingeschlossenen Patienten jeweils mehrere in Paraffin eingebettete Tumorresektate vorhanden sind. Von diesen studierte die Dissertantin jeweils den zugehörigen HE-Schnitt und bestimmte den für die TMA-Konstruktion verwertbarsten Tumorblock. Die bei den Operation entnommen Sentinel-Lymphknoten wurden ebenfalls angefordert. Danach erfolgte die Identifizierung des gewünschten Paraffinblockes im Archiv und eine erneute Anfertigung eines HE-Schnittes. Auf diesem zeichnete die Dissertantin unter dem Mikroskop die beste stanzbare Region im Tumor ein. Ziel war es, auf dem später entnommenen Core nur Anteile der invasiven Tumorfront ohne Verhornungen oder normalen Gewebes zu haben. Im Falle der Sentinel-Lymphknoten erfolgte die Beurteilung, ob es quantitativ genug Tumormaterial für eine Core-Entnahme vorhanden ist. Um eine hohe Aussagekraft des TMA gewährleisten zu können, wurde jede von der Dissertantin ausgewählte Region in Zusammenarbeit mit einem Pathologen nochmals verifiziert und gegebenenfalls ein anderer Tumorblock ausgewählt und neu eingezeichnet.

Anhand des HE-Schnittes als Orientierungshilfe wurde aus dem Paraffinblock mit Tumorgewebe („Spender“) ein Gewebezylinder entnommen und dieser sorgfältig in einen neuen Paraffinblock („Empfänger“) eingefügt. Um den Nachteil auszumerzen, dass der ausgestanzte Gewebeausschnitt nicht repräsentativ für das gesamte Gewebe sein könnte, wurden je zwei Cores pro Patient genommen. Bei teilweise sehr kleinen Tumormassen erfolgte dies in enger Zusammenarbeit der Dissertantin mit der Leiterin des TMA-Labors, um eine hohe Qualität des TMA gewährleisten zu können. Es wurde für den TMA einen Stanzendurchmesser von $0.6 \mathrm{~mm}$ und eine Höhe von 3-4 mm gewählt. Nachdem der „Empfänger“Paraffinblock mit Cores der Patienten bestückt worden war, wurde der Block in 4.0um dünne Scheiben geschnitten, deparaffiniert, rehydriert und mit den primären Anitkörpern inkubiert. Die Färbung wurde mit dem automatischen Ventana Benchmark Färbesystem erstellt. Diese Arbeit erfolgte durch das TMA-Labor.

Jeder einzelne Core wurde von der Dissertantin und dem Dissertationsbetreuer mit dem virtuellen Mikroskop des Universitätsspitals Zürich analysiert und nach dem Immunreactivity Score (IRS) bewertet. Der IRS ist eine Skala zur Quantifizierung der immunhistochemischen Anfärbung, die durch das Multiplizieren der Anteile der angefärbten Zelle mit der Färbeintensität entsteht. Da pro Patient zwei Cores gefärbt wurde, wurde durch die Dissertantin jeweils der Durchschnitt der IRSs berechnet und für die weiteren statistischen Analysen verwendet. 
Zuerst erfolgte die immunhistochemische Auswertung der pro Färbung insgesamt 262 Cores von E-Cadherin, p16, Cyclin D1 und EGFR, nachfolgend die Analyse von N-Cadherin, Periostin, Vimentin, Podoplanin sowie später SOX-2 in Zusammenarbeit mit Dr. med. M. Roessle.

Für die klinische Korrelation oblag es der Dissertantin, im Klinikinformationssystem die Daten des Follow ups der Patienten zusammenzustellen. 13 Patienten mussten schlussendlich wegen fehlendem Follow up oder nicht auswertbarem TMA ausgeschlossen werden. Der IRS wurden dann mit dem Status der Senitellymphknoten sowie der Rezidivrate korreliert. Die statistischen Signifikanz wurde durch den Log-Rank-Test sowie durch das Regressionsmodell nach Cox ermittelt.

Daraus erfolgten die Publikationen „Down regulation of E-Cadherin (ECAD) - a predictor for occult metastatic disease in sentinel node biopsy of early squamous cell carcinomas of the oral cavity and oropharynx“, „Podoplanin expression correlates with sentinel lymph node metastasis in early squamous cell carcinomas of the oral cavity and oropharynx" jeweils mit der Erstautorenschaft von PD Dr. med. G. Huber, sowie auf deren Grundlage „EGFR expression and copy number changes in low T-stage oral squamous cell carcinomas“ von Dr. med. M. Roessle. Die Publikation „High sex determining region Y-box 2 expression is a negative predictor of occult lymph node metastasis in early squamous cell carcinomas of the oral cavity“ wird nun als geteilte Erstautorenschaft von Dr. med. M. Rössle und der Dissertantin angeführt. 


\section{Curriculum Vitae}

\section{Lena Züllig von Bülach ZH}

12.12.1987 geboren in Zürich ZH

1994 - 2000 Primarschule Wädenswil ZH

2000 - 2006 Gymnasium Stiftsschule Einsiedeln SZ

$2006 \quad$ Matur mit Schwerpunkt Italienisch, Einsiedeln SZ

2006 - 2012 Studium der Humanmedizin an der Medizinischen Fakultät der Universität Zürich, Zürich ZH

2012 Eidgenössische Prüfung der Humanmedizin an der Universität Zürich, abgelegt am Universitätsspital Zürich ZH

Seit 05/2013 Assistenzärztin Innere Medizin, Spital Einsiedeln SZ 